\title{
Uji Aktivitas Antiulcer Air Alkali Terionisasi Pada Mencit Putih Jantan (Mus Musculus)
}

\author{
Adriyan Suhada ${ }^{1}$, Bq. Fitria Maharani ${ }^{2}$, Ni Komang Wijiani Yanti ${ }^{3}$, , Nur'aini ${ }^{4}$ \\ ${ }^{1234}$ FakultasKesehatan, UniversitasNahdlatulUlama NTB \\ Email: adriyan_suhada@yahoo.com
}

\begin{abstract}
Abstrak. Air alkali merupakan air yang memiliki kandungan antioksidan dan memiliki struktur yang kaya hidrogen aktif yang dapat menyembuhkan tukak lambung.Tujuan penelitian ini adalah untuk mengetahui efektifitas air alkali terionisasi sebagai antiulcer pada mencit putih jantan (mus musculus). Metode induksi tukak lambung menggunakan aspirin, digunakan sebanyak 24 mencit jantan (mus musculus) berumur 2-3 bulan digunakan sebagai hewan uji mencit dibagi menjadi 6 kelompok masing-masing kelompok terdiri dari 3 ekor semua kelompok diberi perlakuan ulser selama 7 hari, selanjutnya kelompok I (kontrol negatif) diberi aquadest kelompok II (kontrol positif) diberi sukralfat, kelompok III diberi air alkali ph 8,5 kelompok IV diberi air alkali ph 9,0, kelompok V diberi air alkali ph 9,5, dan kelompok VI diberi air alkali ph 11,5 perlakuan masing-masing kelompok selama 7 hari selanjutnya pada hari ke -14 mencit dibedah dan diamati struktur mukosa lambung dan ditentukan nilai kerusakan mukosa. Hasil penelitian menunjukan bahwa air alkali ph 9,5 dan 11,5 memiliki nilai kerusakan mukosa lebih rendah dibandingkan kontrol negatif. Maka dapat disimpulkan bahwa air alkali ph 9,5 dan 11,5 dikatakan efektif menurunkan kerusakan mukosa lambung dibandingkan dengan kelompok negatif yang diberikan aquadest.
\end{abstract}

Kata kunci: Air Alkali, Ulcer,Mukosa Lambung.

Abstract. Alkaline water is water that has antioxidant content and has a structure that is rich in active hydrogen that can cure stomach ulcers. The purpose of this study was to determine the effectiveness of ionized alkaline water as an antiulcers in male white mice (mus musculus). Method of induction of gastric ulcer using aspirin, used as many as 24 male mice (mus musculus) aged 2-3 months used as mice test animals divided into 6 groups each group consisting of 3 animals all groups were given ulcer treatment for 7 days, then group I (negative control) were given aquadest group II (positive control) were given sucralfate, group III were given ph 8 alkaline water group IV was given ph 9.0 alkaline water, group V was given ph 9.5 alkaline water, and group VI was given alkaline water $\mathrm{pH} 11.5$ treatment of each group for the next 7 days on the 14th day the mice were dissected and the gastric mucosa structure was observed and the mucosal damage value was determined. The results showed that alkaline water 9.5 and 11.5 had lower mucosal damage values than negative controls. It can be concluded that the alkaline water ph 9.5 and 11.5 are said to be effective in reducing gastric mucosal damage compared to the negative group given aquadest.

Keywords: Alkaline Water, Ulcers, Gastric Mucosa

\section{PENDAHULUAN}

Tingkat kesadaran masyarakat Indonesia masih sangat rendah mengenai pentingnya menjaga kesehatan lambung, padahal sakit maag akan sangat mengganggu aktivitas sehari-hari, baik remaja maupun orang dewasa. Ulkus peptikum merupakan penyakit yang umum di dunia.Diperkirakan sekitar 5-10\% penduduk amerika serikat menderita penyakit ini selama hidupnya. Ulkus duodenum terjadi dua atau tiga kali lebih sering pada laki-laki, terutama pada usia 50 tahun. Ulkus peptikum terjadi pada semua usia paling sering terjadi pada usia 20-40 tahun (Taylor, 2005).

Masyarakat harus menghindari faktor yang bisa menyebabkan tukak lambung diantaranya yaitu konsumsi rokok, alkohol, dan konsumsi obat obatan anti nyeri secara terus menerus ada beberapa factor yang dapat menyebabkan tukak lambung diantaranya dikarenakan terinfeksi bakteri helicobacterium pylori (H. Pylori), stress, konsumsi rokok dan alkohol, dan penggunaan obat-obatan golongan antiinflamasi Nonsteroid (OAINS) (Goodman \& Gilman 2007). 
Ulkus peptikum atau tukak lambung yang bahasa sehari-hari disebut maag adalah kondisi terjadinya kerusakan mukosa lambung yang diikuti oleh proses inflamasi (katzung, 1998). Cara pencegahan terbentuknya tukak lambung diantaranya dengan cara pemberian obat yang dapat berfungsi sebagai sitoprotektif pada mukosa lambung, penghambatan proton atau antagonis $\mathrm{H} 2$, analog prostaglandin dan penurunan motilitas lambung (Neal, 2006).

Salah satu obat yang digunakan adalah sukralfat. Kemajuan ilmu pengetahuan dan teknologi pada bidang ilmu kefarmasianmenimbulkan perkembangan dan inovasi penemuan obat baru yang berasal dari obat tradisional mulai berkembang pesat, pengobatan yang cukup dikenal dalam dunia kesehatan adalah pengobatan sintetik maupun alamiah, contoh obat sintetik yang umunya dikonsumsi untuk mengobati tukak lambung atau biasa disebut dengan maag yaitu simetidin, ranitidin, famotidin, nizatidin, yang bekerja dengan cara bekerja dengan cara memblok reseptor kerja histamin pada sel parietal dan mengurangi sekresi asam (Neal, 2006). Adapun pengobatan tradisional lainnya.Kulit pisang memiliki memiliki aktivitas antioksidan dikarenakan kandungan flavonoid yang terdapat pada kulit pisang, telah berhasil mengisolasi senyawa flavonoid yang diduga memiliki aktivitas antioksidan berpotensi dalam menangkal senyawa radikal bebas pada lambung. Saat ini banyak beredar air alkali yang dijadikan trend medikasi pengobatan oleh masyarakat. Dalam hal ini data dari BPOM menyebutkan ada 10 jumlah air kemasan di Indonesia yang terdaftar. Air Alkali yang sering dikonsumsi oleh masyarakat dengan berbagai merek banyak digunakan untuk tujuan kesehatan dengan harga yang bervariasi, yang diklaim dapat memperbaiki kondisi gout, tukak lambung, bau badan dan lain sebagainya. Penelitian ingin mencoba untuk menggunakan air alkali terionisasi hasil dari mesin kangen water lavelux SD501, sebagai alternative untuk pengobatan tukak lambung.Minimnya dasar ilmiah tentang pengaruh air alkali terionisasi terhadap kejadian tukak lambung, menyebabkan perlu dilakukan penelitian yang ditunjukkan untuk mengetahui apakah air alkali mempunyai efektivitas sebagai antiulcer pada mencit putih jantan (mus musculus).

\section{METODE PENELITIAN}

Penelitian ini merupakan suatu penelitian eksperimental di laboraturium dengan rancangan penelitin acak lengkap (RAL). Dengan 6 kelompok yang terdiri dari masing-masing 4 ekor mencit. Kelompok 1 merupakan kontrol negatif dan diberikan aquadest secara (p.o). Kelompok 2 merupakan kontrol positif, diberikan sukralfat $4 \mathrm{~g} / \mathrm{kg}$ BB. Kelompok 3,4,5, dan 6 merupakan kelompok eksperimen yang diberikan air alkali masing-masing dengan $\mathrm{pH}$ 8.5, $\mathrm{pH}$ 9.0, $\mathrm{pH}$ 9.5, dan $\mathrm{pH} 11.5$.

\section{Alat Dan Bahan}

a. Alat yang di gunakan dalam penelitian ini adalah:

1) Timbangan analitik

2) Spuit Injeksi Volume $3 \mathrm{ml}$

3) Sonde oral

4) Timbangan mencit

5) Kandang mencit

6) Gunting

7) Jarum pentul

8) Penggaris

9) Kaca pembesar

10) Peralatan bedah

11) Sterofom

12) Hanscoon dan masker.

b. Bahan yang di gunakan dalam penelitian ini antara lain

1) Mencit jantan (mus musculus)

2) Air Alkali

3) Pakan mencit (pellet)

4) Aspirin

5) Sukralfat

6) Aquadest

7) $\mathrm{NaCl}$.

\section{Penentuan dosis}

a. Dosis aspirin yang digunakan adalah 4,66 $\mathrm{mg} / \mathrm{kg}$ bb

b. Dosis sukralfat $57 \mathrm{mg} / \mathrm{kg}$ bb

c. Dosis Air Alkali per ph 0,0284 ml/gr bb.

\section{Pemilihan dan Penyiapan Air Alkali}

Air alkali yang digunakan dalam penelitian ini adalah air alkali terionisasi dari mesin kangen water tipe leavelux SD 501 dengan varian $\mathrm{pH} 8,5$, $\mathrm{pH}$ 9.0, pH 9,5 dan $\mathrm{pH} 11,5$.

\section{Uji Efek Antiulcer}

Mencit dibagi menjadi 6 kelompok, kelompok kontrol dan kelompok hewan uji yang masingmasing kelompok terdiri dari 3 ekor mencit 
kelompok kontrol negatif yang diberikan aquadest, kelompok positif yang diberikan sukralfat $57 \mathrm{mg}$ $\mathrm{kgBB}$ dan kelompok uji terdiri atas kelompok mencit yang diberi air alkali ( ph 8,5 ph 9.0, ph 9,5 dan ph 11,5 sebanyak $0,0284 \mathrm{ml} / \mathrm{kg}$ BB. Hewan uji dibagi menjadi 24 ekor dibagi menjadi 6 kelompok sama banyak yaitu:
1). Kelompok I
: Kontrol negatif diberikan aquadest secara (p.o)

2). Kelompok II

: Kontrol positifdiberikan sucralfat dosis 577 $\mathrm{mg} / \mathrm{kgBB}$, secara peroral. Yang diinduksi aspirin 4,66 $\mathrm{mg} / \mathrm{kg}$ bb secara peroral

3). Kelompok III : Diberikan air alkali Ph 8,5. $0,0284 \mathrm{ml} / \mathrm{kgBB}$ secara peroral yang diinduksi aspirin 4,66 mg/kg bb secara peroral.

4). Kelompok IV : Diberikan air alkali Ph 9,0. $0,0284 \mathrm{ml} / \mathrm{kgBB}$ secara peroral.yang diinduksi aspirin 4,66 mg/kgBB secara peroral.

5). Kelompok V : Diberikan air alkali $\mathrm{Ph}$ 9,5.Sebanya0,0284ml $/ \mathrm{kg}$ BB secara peroral.yang diinduksi aspirin 4,66 $\mathrm{ml} / \mathrm{kg}$ bb secara peroral.

6). Kelompok VI : Diberikan air alkali Ph 11,5. $0,0284 \mathrm{ml} / \mathrm{kgBB} \quad$ secara peroral.yang diinduksi aspirin $4,66 \mathrm{ml} / \mathrm{kg}$ bb secara peroral.

\section{Analisis data}

Data yang yang diperoleh dianalisis menggunakan uji statistic one way ANOVA dengan tingkat kepercayaan $95 \%$ untuk perbedaan nilai kerusakan mukosa lambung masing-masing kelompok.

\section{HASIL DAN PEMBAHASAN}

Hasil Penelitian

Tabel I. Nilai Kerusakan Mukosa Lambung

\begin{tabular}{|c|c|c|}
\hline Kelompok & Perlakuan & $\begin{array}{l}\text { Rata-rata nilai } \\
\text { kerusakan } \\
\text { mukosa lambung }\end{array}$ \\
\hline I & $\begin{array}{c}\text { Kontrol ulcer } \\
+ \text { aquadest }\end{array}$ & 0,867 \\
\hline II & $\begin{array}{c}\text { Kontrol ulcer } \\
+ \text { sukralfat }\end{array}$ & 0,133 \\
\hline
\end{tabular}

\begin{tabular}{|c|c|c|}
\hline III & $\begin{array}{c}\text { Kelompok } \\
\text { ulcer + ph 8,5 }\end{array}$ & 0,400 \\
\hline IV & $\begin{array}{c}\text { Kelompok } \\
\text { ulcer+ ph 9.0 }\end{array}$ & 0,100 \\
\hline V & $\begin{array}{c}\text { Kelompok } \\
\text { ulcer+ ph 9,5 }\end{array}$ & 0,000 \\
\hline VI & $\begin{array}{c}\text { Kelompok } \\
\text { ulcer + ph } \\
11,5\end{array}$ & 0,000 \\
\hline
\end{tabular}

Gambar berikut menunjukan struktur mukosa lambung

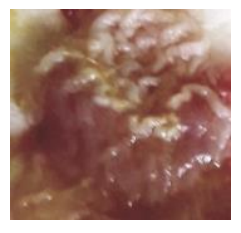

(a). kontrol negatif aquades

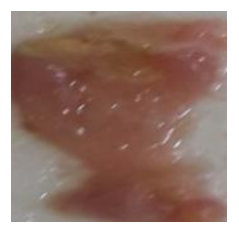

(b). kontrol positif (sukralfat)

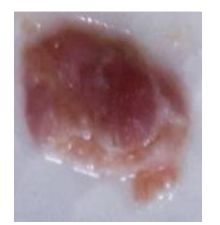

(c). air alkali ph 8,5

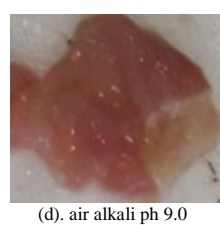

(d). air alkali ph 9.0

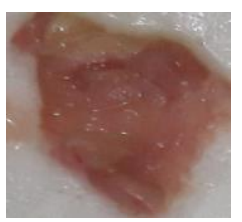

(e). air alkali ph 9,5

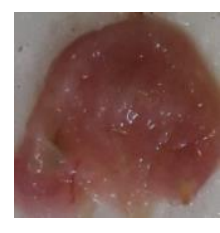

(f). air alkali ph 11,5
Tabel 2. Uji Anova

\begin{tabular}{|l|l|l|l|l|l|}
\hline & $\begin{array}{l}\text { Sum of } \\
\text { square }\end{array}$ & Df & $\begin{array}{l}\text { Mean } \\
\text { square }\end{array}$ & F & sig \\
\hline $\begin{array}{l}\text { Betwen } \\
\text { groups }\end{array}$ & 1.692 & 5 & 0,338 & 3.346 & 0,040 \\
\hline $\begin{array}{l}\text { Within } \\
\text { groups }\end{array}$ & 1.213 & 12 & 0,101 & & \\
\hline Total & 2.905 & 17 & & & \\
\hline
\end{tabular}

Tabel 3. Tukey HSD

\begin{tabular}{|l|r|r|}
\hline \multirow{2}{*}{ Perlakuan } & & Subset for alpha=0,05 \\
\cline { 2 - 3 } & $\mathrm{N}$ & 1 \\
\hline PH 9,5 & 3 & 0,000 \\
\hline PH 11,5 & 3 & 0,000 \\
\hline PH 9.0 positif & 3 & 0,100 \\
\hline $\begin{array}{l}\text { Kontrol } \\
\text { (sukralfat) }\end{array}$ & 3 & 0,133 \\
\hline
\end{tabular}




\begin{tabular}{|l|l|r|}
\hline Ph 8,5 & 3 & 0,400 \\
\hline $\begin{array}{l}\text { Kontrol } \\
\text { negative } \\
\text { (aquadest) }\end{array}$ & 3 & 0,867 \\
\hline Sig & & 0,52 \\
\hline
\end{tabular}

\section{Pembahasan}

Dari hasil analisis ANOVA pada tabel II, dapat dilihat bahwa terdapat perbedaan kerusakan mukosa lambung yang signifikan antara perlakuan dengan nilai sig 0,040 atau $(p<0,05)$. Karena syarat dikatakan signifikan yaitu nilai ( $p>0,05)$, sehingga dilanjutkan dengan pengujian post hoc test dengan metode tukey $\boldsymbol{H S D}$, yang dapat menjelaskan tentang perbandingan masing-masing kelompok.

Dari hasil Tukey HSD pada tabel III, menunjukan nilai sig $0,052>0,05$. Hal ini berarti tidak ada perbedaan secara signifikan terhadap perlakuan. Berdasarkan hasil analisis statistik menunjukkan bahwa tidak terdapat perbedaan yang signifikan $(0,052>0,05)$ atau $(\mathrm{p}>0,05)$ pada tingkat kerusakan mukosa lambung dari seluruh perlakuan. Walaupun demikian, jika dibandingkan antara kelompok mencit ulser yang diberi air alkali (kelompok V) pH 9.5 dan (kelompok VI) pH 11.5, tampak bahwa tingkat kerusakan mukosa lambung yang lebih rendah, dibandingkan dengan kelompok mencit ulser yang hanya diberikan aquadest (kelompok negatif).

Berdasarkan hasil penelitian ini diketahui bahwa hewan uji yang diinduksi dengan aspirin selama 7 hari dapat membentuk ulkus peptikum (ulser lambung). Aspirin pada penelitian ini digunakan sebagai faktor agresif (perusak) pada lambung. Menurut Sangelorang (1998) dosis aspirin yang dapat merusak lambung mencit adalah 4,66 $\mathrm{mg} / \mathrm{kg} \mathrm{BB}$.

Penelitian ini menggunakan metode induksi aspirin yang merupakan uji praklinik, sehingga lebih mendekati keadaan kerusakan mukosa pada hewan uji. Mekanisme aspirin dalam merusak mukosa lambung adalah efek topikal yang terjadi karena aspirin bersifat asam dan lipofilik. Sehingga memudahkan obat masuk bersama $\mathrm{H}^{+}$dan terperangkap di dalam sel. Selanjutnya terjadi pembengkakan disertai proses inflamasi dan akan terjadi kerusakan sel epitel tersebut (philipson et al., 2008).
Kelompok hewan uji untuk kontrol positif yaitu sukralfat dengan dosis $577 \mathrm{mg} / 20 \mathrm{~g} \mathrm{BB}$. Sukralfat ini melibatkan polimerasi dan selektif terhadap jaringan ulkus. Bahan ini bertindak sebagai penghalang terhadap asam, pepsin dan cairan empedu (katzung, 2004). Dalam suasana asam (perut kosong) obat ini akan membentuk pasta kental yang terikat pada protein di permukaan ulkus yang tahan terhadap hidrolisis pepsin. Dengan demikian sukralfat dapat melindungi ulkus terhadap difusi asam (paramita dkk ., 2012).

Hasil dari uji tukey HSD adalah pada perlakuan $\mathrm{pH}$ 9,5 nilai kerusakan mukosa 0,000, tidak ada perbedaan dengan perlakuan pemberian $\mathrm{pH} 11,5$ dengan nilai 0,000 , pada perlakuan pemberian $\mathrm{pH}$ 9,0 nilai kerusakan mukosa 0,100, perlakuan pemberian sukralfat pada kontrol positif memiliki nilai kerusakan 0,133 , pada pemberian $\mathrm{pH}$ 8,5 memiliki nilai kerusakan mukosa 0,400 , dan pada perlakuan kontrol negatif memiliki nilai kerusakan mukosa 0,867 perlakuan kelompok ini dikatakan nilai kerusakan mukosa paling tinggi, jika dibandingkan dengan ph 11,5 . nilai kerusakan mukosa paling rendah yaitu perlakuan pemberian $\mathrm{pH}$ 9,5 dan pemberian $\mathrm{pH}$ 11,5, pemberian $\mathrm{pH} 11,5$ dengan kontrol positif (sukralfat), pada kelompok perlakuan pemberian sukralfat nilai kerusakan mukosa lebih tinggi dari pada $\mathrm{pH}$ 11,5.dapat dikatakan bahwa $\mathrm{pH}$ 9,5 dan $\mathrm{pH}$ 11,5 dapat menurunkan nilai kerusakan lambung dari pada kontrol positif.

Air alkali mengacu pada elektrolisis air yang dihasilkan dari mineral seperti magnesium dan kalsium, yang dicirikan oleh hidrogen yang sangat tinggi, ph tinggi , air yang kaya hidrogen ini telah diperkenalkan sebagai strategi terapi untuk pencegahan dan pengobatan penyakit.

\section{KESIMPULAN}

Berdasarkan hasil penelitian yang telah dilakukan maka dapat disimpulkan sebagai berikut:

1. Air alkali terionisasi memiliki aktifitas antiulcer, hal ini ditunjukkan oleh terjadinya penurunan nilai kerusakan lambung pada mencit putih jantan (mus musculus).

2. Air alkali terionisasi efektif sebagai antiulcer dengan pemberian $\mathrm{pH} 9.5$ dan $\mathrm{pH} 11.5$ pada mencit putih jantan (mus musculus).

\section{DAFTAR PUSTAKA}


BPOM, 2008, Informatorium Obat Nasional Indonesia, 690-692.

Goodman Dan Gilman, 2007, Dasar Farmakologi Dan Terapi, Ed. X, Jakarta.Penerbit Buku Kedokteran Egc.

Katzung , B.G., 1998, Farmakologi Dasar Dan Terapi, EGC, Jakarta.

Katzung, B. G., 2004, Farmakologi Dasar dan Klinik, Edisi XIII. Buku 3.Translation of Basic and Clinical Pharmacology Eight Edition Alih bahasa oleh Bagian Farmakologi Fakultas kedokteran Universitas Airlangga, Jakarta: Salemba Medika.

Neal, M.J., 2006, Obat Yang Bekerja Pada Saluran Gastrointestinal I: Ulkus Peptikum.

Parakrama Chandrasoma Clive R.Taylor, 2005, Ringkasan Patologi Anatomi Edisi 2, Jakarta: EGC.

Paramita , D.A., Y.W., Wardhana, A. Wisnu dan Sudirman, 2012, Analisis Sucralfat Pasca Kalsinasi Pada Mukosa Lambung, Indonesian journal of material science.

Sangelorang,S., 1998, Pengaruh Ekstrak Etanol Rimpang Jahe (Guazuma Ulmifolia Lamk) Terhadap Tukak Lambung Yang Diinduksi Aspirin Pada Tikus Puti, Skripsi, FK UGM, Yogyakarta. 